\title{
EFFECTS OF THE APPLICATION OF A MINERAL-AND-ORGANIC FERTILISER PRODUCED FROM BROWN COAL ON THE OCCURRENCE AND INFECTIOUS POTENTIAL OF ENTOMOPATHOGENIC FUNGI IN SOIL
}

\author{
Anna Majchrowska-Safaryan', Cezary Tkaczuk', Barbara Symanowicz² \\ 1 Department Plant Protection and Breeding, Siedlce University of Natural Science and Humanities, B. Prusa \\ 14, 08-110 Siedlce, Poland, e-mail: anna.majchrowska-safaryan@uph.edu.pl \\ 2 Department of Soil Science and Agricultural Chemistry, Siedlce University of Natural Science and Humanities, \\ B. Prusa 14, 08-110 Siedlce, Poland
}

Received: 2017.03.13 Accepted: 2017.04.04 Published: 2017.05.02

\begin{abstract}
This study compared the species composition and rate of entomopathogenic fungi occurrence in cultivable soil following the application of a mineral-and-organic fertiliser produced from brown coal. The material for testing consisted of soil samples collected in the second year of the experiment on two dates in 2015 (spring and autumn). The experiment was carried out on the following plots: control plot (no fertilisation); a plot fertilised with mineral fertilisers NPK presowing $+\mathrm{N}_{60}$ for top dressing; a plot fertilised with NPK presowing + manure; a plot fertilised with a fertiliser produced from brown coal at a dose of $1 \mathrm{t}$ /ha NPK presowing $+\mathrm{N}_{20}$ for top dressing; and a plot fertilised with a fertiliser produced from brown coal at a dose of $5 \mathrm{t} / \mathrm{ha}$ NPK presowing $+\mathrm{N}_{40}$ for top dressing. Entomopathogenic fungi were isolated from soil of particular fertilisation experiment plots using insect traps (Galleria mellonella larvae) as well as a selective medium. Three species of entomopathogenic fungi, i.e. Beauveria bassiana, Metarhizium anisopliae s.1. and Isaria fumosorosea, were isolated using two methods, from the soil samples collected from particular fertilisation experiment plots on two dates, i.e. spring and autumn. Fungus $M$. anisopliae s.l. proved to be the predominant species in the tested soil samples. The addition of the mineral-and-organic fertiliser, produced based on brown coal, to the soil at both applied doses contributed to an increase in the number of infectious units (CFUs) of entomopathogenic fungi formed in relation to the control plot.
\end{abstract}

Keywords: entomopathogenic fungi, cultivable soil, fertilisation, brown coal

\section{INTRODUCTION}

Research into the use of brown coal in agriculture was carried out in Poland as early as before the Second World War. Musierowicz [1938] claimed that brown coal could be used to improve the properties of light soils. Górska et al. [2006] noted the positive effects of brown coal on the functioning of soil microflora. It is an organic material which, under field conditions, is subject to gradual biodegradation in which root exudates also participate. Mineral-and-organic fertilisers produced from brown coal may be used in organic production as well as in integrated and conven- tional production. They are innovative, pro-environmental, and "complex" fertilisers [The Act... 2007, 2012]. The organic matter of brown coal used in these fertilisers is subject to slow degradation and improves the soil properties on a long term basis. They are a significant source of nutrients and control the soil solution concentration by means of sorption and release of various ions and chemical compounds to the solution [Sas-Paszt et al. 2013, Symanowicz et al. 2013].

Organic agriculture is an important tool in the strategy to improve the conditions of environmental protection and the development of agriculture, which are the main objectives of the 
Community's agricultural policy. Therefore, the use of fertilisers produced from brown coal may provide an effective alternative to mineral fertilisation and be a key solution in the development of organic production of crops at both the national and European level. Another important component of the natural environment, which is also one of the groups of beneficial microorganisms which may be used to protect cultivated organic crops and improve the natural environment, are entomopathogenic fungi [Karg and Bałazy 2009]. As natural enemies, they play an important role in the processes of biocenotic control of populations of numerous insect and acarid species and some of them provide a basis for the production of bioinsecticides increasingly used in the biological protection of plants [Faria and Wright 2007, Tkaczuk 2008, Tkaczuk et al. 2013, 2016a,b, Sosnowska 2013]. Currently, biopreparations produced on the basis of entomopathogenic fungi are primarily used in protected crop cultivation, on meadows used for grazing and in vegetable and fruit farming [Goetel et al. 1995, Bałazy 2004, Sosnowska, 2013, Tkaczuk et al. 2016b]. These preparations are also increasingly used in integrated agricultural production systems. As regards the biological control of plant pests, virulent strains of anamorphous Ascomycetes (Ascomycota, Hypocreales) of the following genera: Beauveria, Hirsutella, Isaria, Lecanicillium, or Metarhizium, are most widely used.

Fertilisation, due to the prevalence of its use, is one of the most frequent factors affecting both the occurrence and the infectious potential of entomopathogenic fungi in cultivable soils [Hirose et al. 2001, Gorczyca 2006, Klingen and Haukeland 2006, Tkaczuk 2008]. Many years of fertilisation with organic materials contributing to an increase in the amount of organic matter in soils has a positive effect on the population of entomopathogenic fungi, while the application of high doses of mineral fertilisers (in the form of NPK) is a factor which may restrict their infectious potential [Rosin et al. 1996, Ali-Shtayeh et al. 2002, Klingen et al. 2002, Quesada-Moraga et al. 2007, Tkaczuk, 2008].

The aim of this study was to compare both the species composition and the rate of occurrence of entomopathogenic fungi in cultivable soil following the application of various fertilisation variants, including a mineral-and-organic fertiliser produced from brown coal.

\section{MATERIAL AND METHODS}

The material for testing consisted of soil samples collected in the second year following the application of a mineral-and-organic fertiliser produced from brown coal on two dates in 2015, i.e. in the spring and in the autumn, at the Agricultural Experimental Station of the Siedlce University of Natural Sciences and Humanities, situated in the village of Zawady. Soil samples were collected from five fertilisation experiment plots on which silage maize was cultivated. Soil samples were taken with a scoop to a depth of $20 \mathrm{~cm}$ from five randomly-distributed sites on each plot. Prior to the establishment of the experiment, a soil test pit was dug to a depth of $150 \mathrm{~cm}$. It was described in morphological terms and qualified as sandy grey-brown podzolic soil with a granulometric composition of the humus horizon of loamy sand. The $\mathrm{pH}$ of the fertilisation experiment plots ranged from 4.0 to 4.6 . The experiment was carried out on the following plots: control plot (no fertilisation); a plot fertilised with mineral fertilisers NPK presowing $+\mathrm{N}_{60}$ for top dressing; a plot fertilised with NPK presowing + manure; a plot fertilised with a fertiliser produced from brown coal at a dose of $1 \mathrm{t} /$ ha NPK presowing $+\mathrm{N}_{20}$ for top dressing; and a plot fertilised with a fertiliser produced from brown coal at a dose of $5 \mathrm{t} / \mathrm{ha}$ NPK presowing $+\mathrm{N}_{40}$ for top dressing.

Entomopathogenic fungi were isolated from the soil of particular fertilisation experiment plots using two methods: the trap insect method proposed by Zimmermann [1986] and a selective medium developed by Strasser et al. [1996] (L3 stage) larvae of the greater wax moth Galleria mellonella were used as the trap insect. Five plastic boxes with a capacity of approx. $200 \mathrm{ml}$ were filled with soil from each fertilisation experiment plot. Ten G. mellonella larvae were put into each box, i.e. a total of 50 larvae were put into the soil from each fertilisation combination. The soil-filled boxes were placed in an incubator at $22-23^{\circ} \mathrm{C}$. The first mortality check was carried out after 7 days from the establishment of the experiment and then at 3-day intervals until all the larvae had died. Dead larvae were washed in distilled water and then surface-sterilised for 30 seconds in a $1 \%$ solution of sodium hypochlorite. After being rinsed twice in distilled water, the larvae were placed in Petri dishes lined with moistened filter paper. The dishes with the larvae were kept in incubators at $20-22^{\circ} \mathrm{C}$ in dark con- 
ditions. The fungi developing on the insects, as well as their spores, were macroscopically tested and microscopic specimens were then prepared, which enabled the determination of the species to which the fungi found on the insects belonged. The fungi were identified on the basis of morphological characteristics, using standard identification keys [Inglis et al. 2012, Humber 2012]. Given that only morphological methods were applied during the identification of the fungi, the species Metarhizium anisopliae was defined sensu lato, because, as demonstrated by the latest phylogenetic studies based on DNA sequence [Bishoff et al. 2006, 2009], there are numerous fungus species within the genus of Metarhizium, which are impossible to distinguish from each other without the application of molecular methods.

During the second part of the experiment, entomopathogenic fungi were isolated from soil of particular fertilisation experiment plots using a selective medium composed of $20 \mathrm{~g}$ of glucose, $10 \mathrm{~g}$ of peptone and $18 \mathrm{~g}$ of agar-agar, which was dissolved in 11 of distilled water, and then sterilised in an autoclave at $120^{\circ} \mathrm{C}$ for 20 minutes. The prepared medium was then cooled to approx. $50^{\circ} \mathrm{C}$ and the following selective components were added: $0.6 \mathrm{~g}$ of streptomycin, $0.05 \mathrm{~g}$ of tetracycline and $0.1 \mathrm{~g}$ of dodine. The selective medium was poured into Petri dishes with a diameter of $9 \mathrm{~cm}$.

From each soil sample originating from a particular fertilisation experiment plot, $2 \mathrm{~g}$ of soil was weighed and then poured over with $18 \mathrm{ml}$ of distilled water with the addition of a Triton X-100 surface tension reducing agent. The obtained solution was shaken for approx. 2 minutes. $0.1 \mathrm{ml}$ of soil solution was taken using an automatic pipette and then poured onto the surface of the selective medium and distributed over the surface using a glass spatula.

The experiment was carried out in three replications for each soil sample. The dishes were then transferred to a heat chamber. After 7-10 days, the number of colony-forming units (CFUs) of particular species of entomopathogenic fungi, developing on the culture medium, were counted. At the final stage, colony-forming units (CFUs) of particular fungus species in $1 \mathrm{~g}$ of dry soil were counted.

The obtained results were processed statistically using the analysis of variance for a single, three-factor experiment in a completely random design, in which the tested factors included the following: A - the date of soil sample collec- tion; $\mathrm{B}$ - fertilisation variant; $\mathrm{C}$ - fungus species. Conclusions concerning the effects of experimental factors on the values of tested characteristics were drawn based on the Fisher-Snedecor test results and the NIR values at $\mathrm{p}=0.05$ were calculated using Tukey's test.

\section{RESULTS AND DISCUSSION}

Three species of entomopathogenic fungi, i.e. Beauveria bassiana, Metarhizium anisopliae s.l. and Isaria fumosorosea, were isolated using the insect trap method and the method of soil solution inoculation onto a selective medium, from the soil samples collected from particular fertilisation experiment plots on two dates, i.e. in the spring and in the autumn (Table 1, Table 2, Figure 1). The species composition, the number of infected larvae of the insect trap and the density of colony-forming units (CFUs) of entomopathogenic fungi varied depending on the date of soil sample collection as well as on the applied fertilisation variant.

The count of microorganisms and their biomass are among the key indicators of the soil microbiological activity [Myśków 1981]. However, their count and activity are determined by numerous biological and abiotic factors. As regards the factors having a major effect on the microbiological activity of soil, special attention should be paid to mineral fertilisation which exerts a selecting effect on microorganisms and leads to disturbances in the nitrogen and carbohydrate metabolism of the microflora inhabiting these soil environments. This, in turn, results in changes to the functioning of entire biocenoses of field and grass ecosystems [Barabasz et al. 1999]. Improper agricultural practices, as well as inappropriate fertilisation, may lead to severe disturbances in soil metabolism and contribute to the formation of various compounds, e.g. nitrosamines or mycotoxins, in the soil environment, which, due to their toxic effects, have an adverse impact on soil microorganisms and crops [Barabasz et al. 1999].

The current state of knowledge of the effects of mineral and organic fertilisation on the occurrence of entomopathogenic fungi in soil is relatively poor. Few studies, conducted primarily under laboratory conditions, have concerned the effects of mineral [Bajan 1982, Hirose et al. 2001, Gorczyca 2006] or organic fertilisers [Rosin et al. 1996] added to the culture medium on the growth, 
Table 1. Mortality of Galleria mellonella larvae (\%) in soils on individual fertilisation objects

\begin{tabular}{|c|c|c|c|c|c|c|c|c|c|c|}
\hline \multirow{3}{*}{ Factor of mortality } & \multicolumn{10}{|c|}{ Year 2015} \\
\hline & \multicolumn{5}{|c|}{ spring } & \multicolumn{5}{|c|}{ autumn } \\
\hline & $a$ & b & c & d & $\mathrm{e}$ & $a$ & $\mathrm{~b}$ & c & $\mathrm{d}$ & e \\
\hline B. bassiana & - & - & - & - & - & - & 2 & - & - & 4 \\
\hline M. anisopliae s.I. & 78 & 96 & 74 & 76 & 84 & 56 & 50 & 54 & 26 & 4 \\
\hline I. fumosorosea & 4 & - & 10 & - & - & 28 & 36 & 28 & 56 & 26 \\
\hline Total & 82 & 96 & 84 & 76 & 84 & 84 & 88 & 82 & 82 & 34 \\
\hline Aspergillus sp. & 6 & & 6 & 8 & 8 & 2 & - & - & - & - \\
\hline Fusarium sp. & 8 & 4 & 4 & 16 & 8 & 14 & 6 & 18 & 14 & 30 \\
\hline Gilocladium sp. & - & - & - & - & - & - & 2 & - & - & \\
\hline Unsporulated mycelium & 2 & - & - & - & - & - & 4 & - & 4 & 6 \\
\hline Total & 16 & 4 & 10 & 24 & 16 & 16 & 12 & 18 & 18 & 36 \\
\hline Nematodes & - & - & - & - & - & - & - & - & - & 18 \\
\hline Other causes & 2 & - & 6 & - & - & - & - & - & - & 12 \\
\hline Total & 2 & - & 6 & - & - & - & - & - & - & 30 \\
\hline
\end{tabular}

Table 2. The density of colony forming- units of entomopathogenic fungi (CFU x $\left.10^{3} \mathrm{~g}^{-1}\right)$ in soils collected from individual fertilisation objects

\begin{tabular}{|c|c|c|c|c|c|c|c|c|c|c|}
\hline \multirow{3}{*}{ Fungal species } & \multicolumn{10}{|c|}{ Year 2015} \\
\hline & \multicolumn{5}{|c|}{ spring } & \multicolumn{5}{|c|}{ autumn } \\
\hline & $\mathrm{a}$ & $\mathrm{b}$ & $\mathrm{c}$ & $d$ & $\mathrm{e}$ & $\mathrm{a}$ & $\mathrm{b}$ & $\mathrm{c}$ & $d$ & $\mathrm{e}$ \\
\hline Beauveria bassiana & - & - & - & - & - & - & 0.3 & - & - & 0.8 \\
\hline Metarhizium anisopliae s.I. & 1.5 & 6.1 & 2.8 & 4.1 & 3.8 & 1.8 & 2.9 & 1.6 & 3.0 & 2.1 \\
\hline Isaria fumosorosea & 1.2 & 4.1 & 2.6 & 1.9 & 1.1 & 1.6 & 2.1 & 1.2 & 3.1 & 1.4 \\
\hline $\begin{array}{l}\mathrm{LSD}_{0.05} \\
\text { Factor A } \\
\text { Factor B } \\
\text { Factor C }\end{array}$ & \multicolumn{10}{|c|}{$\begin{array}{l}0.952 \\
2.110 \\
1.399\end{array}$} \\
\hline
\end{tabular}

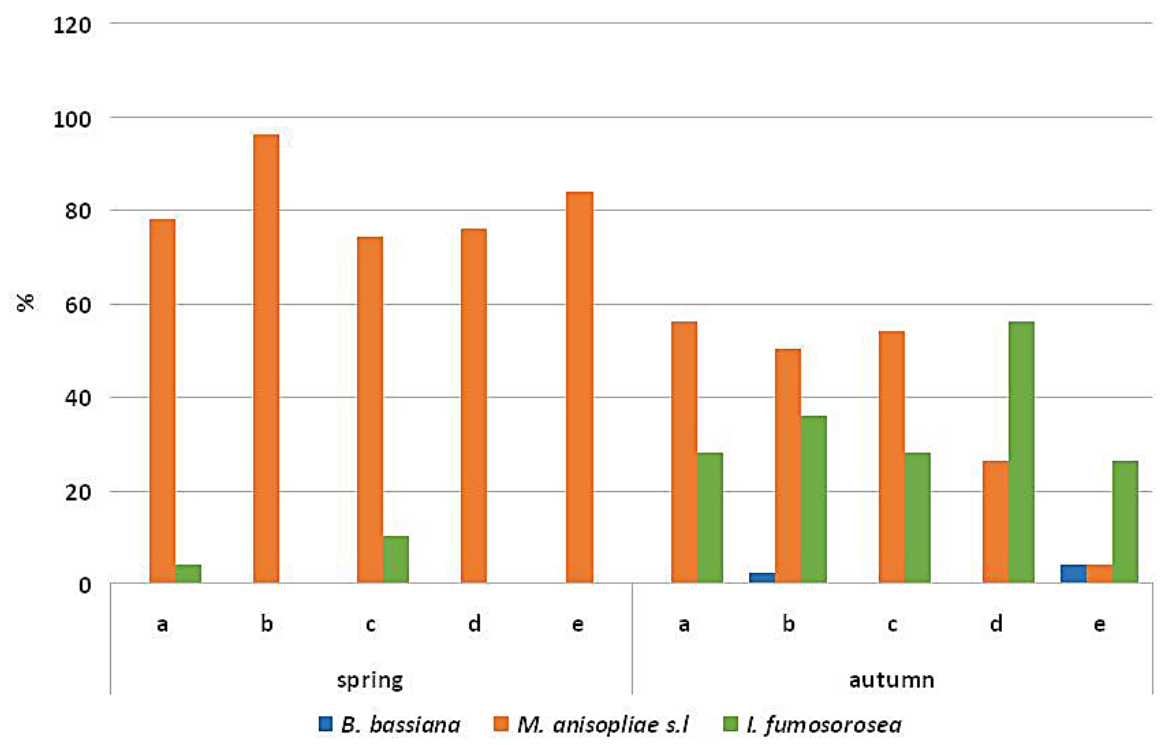

Figure 1. The mortality of Galleria mellonella larvae (\%) in the soils of individual fertilisation objects caused by entomopathogenic fungi

* - explanations as Table 1 
germination and sporulation of entomopathogenic fungi and the possibility for the combined application of fungus $B$. bassiana and mineral fertilisation [Townsend et al. 2003]. Only a few studies have concerned the effects of organic and mineral fertilisation on the rate of entomopathogenic fungi occurrence in soil under field conditions [Jaworska et al. 2002, Jarmuł-Pietraszczyk et al. 2008, Tkaczuk 2008, Jarmuł-Pietraszczyk et al. 2011].

The current study demonstrated that in the soil samples collected in the spring, following the emergence of maize irrespective of the applied fertilisation, the fungus species which caused the highest mortality in G. mellonella larvae was M. anisopliae s.l. (Table 1). This data was confirmed by results of a study by Gondek and Ropek [2007], who concluded that the fungus species most frequently isolated from cultivable soils fertilised with various mineral fertilisers was $M$. anisopliae. This was also confirmed by studies conducted by Keller et al. [2003], Klingen and Haukeland [2006], Quesada-Morgan et al. [2007], Tkaczuk [2008], Tkaczuk et al. [2014, 2016a]. In the author's own study, the percentage of larvae attacked by the fungus ranged from $76 \%$ in the soil collected from the plot fertilised with $1 \mathrm{t} / \mathrm{ha}$ of a fertiliser produced from brown coal, to $96 \%$ in the soil from the plot fertilised only with mineral fertilisers. According to JarmulPietraszyk et al. [2011], long-term mineral fertilisation contributed to the infection of the insect trap larvae by $M$. anisopliae in the soil samples collected in May to a greater extent than in those collected in other months. During the autumn part of the experiment, i.e. after the harvest of maize, a significantly lower percentage of the infection of the insect trap larvae with the fungus $M$. anisopliae s.l. was noted. These values ranged from $4 \%$ to $56 \%$. The highest rate of occurrence of the fungus under study was found in soil collected from the control plot with no fertilisation, while the lowest was found in soils from the fertilisation experiment plot on which the fertiliser produced from brown coal was applied; the values were $5 \mathrm{t} / \mathrm{ha}-4 \%$, and $1 \mathrm{t} / \mathrm{ha}-26 \%$, respectively. Vänninen [1996] concluded that the fungus $M$. anisopliae is a species which is very tolerant towards agricultural practices such as varied fertilisation, ploughing or the application of chemical plant protection products.

The isolation of entomopathogenic fungi onto the selective medium confirmed the clear dominance of the fungus $M$. anisopliae s.l. on all fertilisation experiment plots, during both parts (spring and autumn) of the study (Table 2). Most CFUs formed by this fungus were found during the spring part of the experiment on the plot fertilised with mineral fertilisers $\left(6.1 \times 10^{3} / \mathrm{g}\right)$. On the fertilisation experiment plots on which the fertiliser produced from brown coal was applied, the density of infectious units of the fungus M. anisopliae s.l. was higher than on the control plot (1.5 $\mathrm{x}$ $10^{3} \mathrm{CFU} / \mathrm{g}$ ) and during the spring part of the study and amounted to $4.1 \times 10^{3} \mathrm{CFU} / \mathrm{g}$ (at a dose of 1 $\mathrm{t} / \mathrm{ha}$ ) and $3.8 \times 10^{3} \mathrm{CFU} / \mathrm{g}$ (at a dose of $5 \mathrm{t} / \mathrm{ha}$ ), respectively. During the autumn part of the study, compared to the spring part, the fungus $M$. anisopliae s.l. formed fewer infectious units in soils from the combination in which the fertiliser produced on the basis of brown coal was applied: 3.0 and $2.1 \times 10^{3} \mathrm{CFU}$, respectively, in one gram of soils, yet these values were also higher than those in the control soil. These results confirm the earlier reports of Tkaczuk [2008] who demonstrated that with the increase in the doses of many years' of organic fertilisation, the density of CFUs of the fungus M. anisopliae in soil increased. A significantly greater number of CFUs of this fungus, compared to the control, was found in the variant in which either 60 or $40 \mathrm{t}$ of manure per hectare had been introduced. Tkaczuk et al. [2016a] noted the clear dominance of the fungi $M$. anisopliae and I. fumosorosea in soils originating from fields under cultivation in eastern Poland. They concluded that these fungi formed, respectively, 4.0 x $10^{3}$ and $1.2 \times 10^{3}$ of CFUs in one gram of soil.

During the spring part of the study, the occurrence of the fungus I. fumosorosea was only noted in the soils from two fertilisation experiment plots, i.e. the control plot and the plot fertilised with NPK presowing + manure, and the percentage of infected larvae of G. mellonella was 4\% and 10\% (Table 1). Meyling and Eilenberg [2006] report that the fungus I. fumosorosea is a species that is relatively rarely isolated from cultivable soils. During the autumn part of the study, the occurrence of larvae infected by the fungus $I$. fumosorosea was found in soil samples collected from all fertilisation experiment plots. This infection rate ranged from $26 \%$ to $56 \%$. The clear dominance of this fungus was noted in the soil collected from the fertilisation experiment plot on which the fertiliser produced from brown coal was applied at a dose of $1 \mathrm{t} / \mathrm{ha}$.

The fungus I. fumosorosea formed the most infectious units (CFUs), i.e. $4.1 \times 10^{3} \mathrm{CFU} / \mathrm{g}$ in 
soil samples collected in the spring from the plot fertilised only with mineral fertilisers (Table 2). For the fertilisation experiment plots on which the fertiliser produced from brown coal was applied, the density of infectious units was 1.9 and $1.1 \mathrm{x}$ $10^{3}$ in one gram of soil, respectively. Tkaczuk et al. (2014), who tested soils collected from fields under cultivation, reported that the fungus $I$. $f u$ mosorosea formed more infectious units (CFUs) in soils cultivated under a conventional system than in those cultivated under an organic system. During the autumn part of the study, the density of infectious units of the fungus I. fumosorosea on the fertilisation experiment plot on which the fertiliser produced from brown coal was applied at $1 \mathrm{t} / \mathrm{ha}$ was much higher than that on the control plot and amounted to $3.1 \times 10^{3} \mathrm{CFU} / \mathrm{g}$. On other fertilisation experiment plots, the number of infectious units being formed ranged from 1.2 to $2.6 \times 10^{3} \mathrm{CFUs}$ in one gram of soil. According to Tkaczuk [2008], fungus I. fumosorosea is a species which develops well and forms significantly more infectious units in the soils on which high doses of organic fertilisation are applied. Jarmuł-Pietraszczyk et al. [2011], studied soils fertilised intensively with mineral fertilisers and concluded that particular nutrients introduced to soil have different effects on the pathogenicity of entomopathogenic fungi. According to Bajan and Kmitowa [1997], nitrogen strongly stimulates the growth of B. bassiana and I. fumosorosea, phosphorus stimulates the growth of B. bassiana, $I$. farinosa and I. fumosorosea, while potassium is a nutrient contributing to an increase in the growth rate of the fungus I. farinosa.

The conducted study demonstrated that $B$. bassiana was a species that was least effective in causing the mortality of G. mellonella larvae in the soils under study (Table 1). According to Tkaczuk [2008], the species most frequently isolated from soils of fields under cultivation in Poland, using the insect trap method, included $M$. anisopliae $(85.1 \%)$ followed by I. fumosorosea (77.3\%) and B. bassiana (68.8\%). In the spring, in soil samples collected from particular fertilisation experiment plots, no presence of the fungus $B$. bassiana was found. In the autumn, the rate of infection of larvae with this fungi was also negligible and its presence was only found in soil samples collected from the plot fertilised with mineral fertilisers (2\%, respectively) and from the plot fertilised with the fertiliser produced from brown coal, applied at a dose of $5 \mathrm{t} / \mathrm{ha}$ ( $4 \%$, respectively).
The obtained results differ from those obtained by Jarmuł-Pietraszczyk et al. [2008] who studied the effect of multi-year fertilisation of cultivable soils on the occurrence of entomopathogenic fungi and concluded that the fungus $B$. bassiana infected larvae of the trap insect $G$. mellonella the most in soils fertilised with mineral fertilisers and manure, irrespective of the date of sample collection. The low rate of infection of the insect trap larvae in the author's own study may be due to the fact that the survivability of the conidia of $B$. bassiana capable of infecting is restricted by numerous abiotic factors, including by nitrogen compounds. Rosin et al. [1996] studied the effects of various nitrogen-containing fertilisers on the survivability of $B$. bassiana under laboratory conditions and concluded that uncomposted manure completely prevented the growth of this fungus.

A study carried out using a selective medium confirmed the results obtained using the trap insect method (Table 2). During the spring part of the study, irrespective of the fertilisation variant, no presence of $B$. bassiana was found and during the autumn part, it formed $0.3 \times 10^{3}$ of CFUs in one gram of soil on the plot fertilised only with mineral fertilisers, and $0.8 \times 10^{3}$ on the plot on which the fertiliser produced from brown coal was applied at a dose of $5 \mathrm{t} / \mathrm{ha}$. Tkaczuk et al. [2014] studied the occurrence of entomopathogenic fungi in soils cultivated under a conventional system and concluded that the fungus $B$. bassiana formed significantly fewer infectious units than $M$. anisopliae and I. fumosorosea. Townsend et al. [2003] reported that the survivability of $B$. bassiana in soil is positively affected by fertilisation with phosphorus, magnesium and sulphur in the form of superphosphates. On the other hand, ShapiroIlan Di et al. [2013] reported that the sustainable application of nitrogen fertilisers in orchards has no significant effect on the infectious potential of the insecticidal fungus $B$. bassiana. Gorczyca [2006] demonstrated that the growth of the fungus $B$. bassiana was determined by the $\mathrm{pH}$ values of the applied foliar fertilisers. A micronutrient fertiliser with a $\mathrm{pH}$ value of 5 strongly restricted the surface growth of the fungus species under study, while basic fertilisers stimulated linear growth and a weight increase of the tested strains of entomopathogenic fungus $B$. bassiana.

After assessing the total occurrence of all species of entomopathogenic fungi in soil samples collected from fertilisation experiment plots, the highest density of colony-forming units of ento- 
mopathogenic fungi was found in the spring on the plot fertilised with NPK mineral fertilisers $\left(10.2 \times 10^{3} / \mathrm{g}\right)$, while the lowest density was found on the control plot $\left(1.7 \times 10^{3} / \mathrm{g}\right)$ (Figure 2).

On the plots on which the mineral-and-organic fertiliser produced from brown coal was applied at a dose of $1 \mathrm{t} / \mathrm{ha}$, the infectious unit densities of the entomopathogenic fungi were very similar during both parts of the study. On the other hand, after the application of the fertiliser to soil at a dose of $5 \mathrm{t} / \mathrm{ha}$, more CFUs were found in the spring $(4.9 \mathrm{x}$ $\left.10^{3} / \mathrm{g}\right)$ than in the autumn $\left(4.3 \times 10^{3} / \mathrm{g}\right)$. Tkaczuk et al. [2014] found that for the entomopathogenic fungi form, on average, there were more infectious units in soils originating from cultivation under an organic system in which only organic fertilisers are used than in those originating from conventional cultivation. The application of manure as well as a system of no-plough cultivation of soil has a beneficial effect on the enrichment of the species composition and the number of infectious units formed by entomopathogenic fungi in soils [Bing and Lewis 1993, Sosa-Gomez et al. 2001, Tkaczuk 2008, Karg and Bałazy 2009]. On the other hand, the infectious potential of entomopathogenic fungi is restricted by high doses of mineral fertilisers, the application of chemical plant protection products and soil contamination with heavy metals [Lingg and Donaldson 1981, Rosin et al. 1996, Townsend et al. 2003, Gorczyca 2006, Klingen and Haukeland 2006, Tkaczuk 2008, Tkaczuk et al. 2014, 2016a,b].

A statistical analysis demonstrated that the date of soil sample collection, as well as the ap- plied variant of fertilisation, had a significant effect on the density of infectious units (CFUs) of particular entomopathogenic fungus species (Table 2). This was confirmed by Jaworska et al. [2002], who concluded that the occurrence and diversity of entomoapthogenic fungi in cultivable soils was determined by the type of applied fertilisation as well as the doses of introduced fertilisers.

\section{CONCLUSIONS}

1. Three species of entomopathogenic fungi, i.e. Beauveria bassiana, Metarhizium anisopliae s.l. and Isaria fumosorosea, were isolated from the soil samples collected on two dates from particular fertilisation experiment plots using the insect trap method and the method of soil solution inoculation onto a selective medium.

2. The predominant species in the tested soil samples, both during the spring and the autumn part of the study, proved to be the fungus $M$. anisopliae s.l. The addition of the mineral-andorganic fertiliser, produced from brown coal, to the soil at both applied doses contributed to an increase in the number of infectious units (CFUs) of entomopathogenic fungi formed in relation to the control plot.

3. Having assessed the total occurrence of all species of entomopathogenic fungi, the highest density of colony forming units of these fungi was found in soil samples from the plot fertilised with NPK mineral fertilisers and the lowest density was found on the control plot.

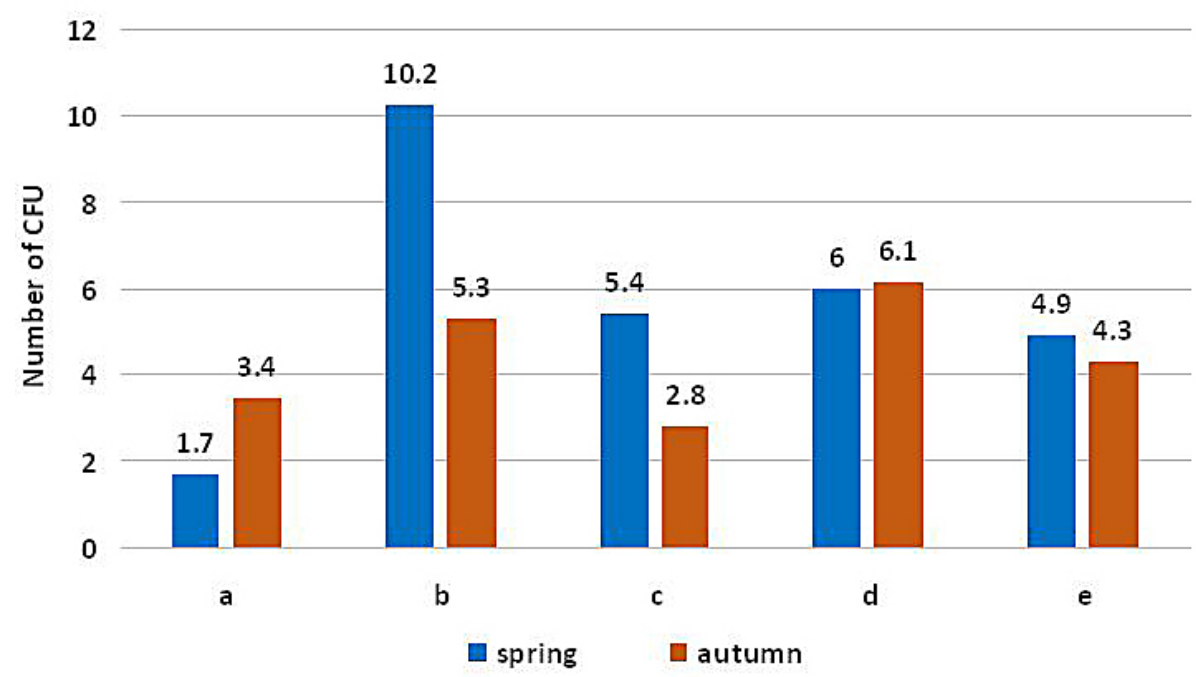

Figure 2. The density of colony forming-units of entomopathogenic fungi (CFU x $\left.10^{3} \mathrm{~g}^{-1}\right)$ in soils collected from individual fertilisation objects

* - explanations as Table 1;CFU - colony forming-units 
4. A statistical analysis demonstrated that the date of the study performance, as well as the applied variant of fertilisation, had a significant effect on the density of infectious units (CFUs) of particular entomopathogenic fungi in soil.

\section{REFERENCES}

1. Ali-Shtayeh M.S., Mara'i A.B.B.M., Jomous R.M. 2002. Distribution, occurrence and characterization of entomopathogenic fungi in agricultural soil in Palestinian area. Mycopathologia, 156, 235-244.

2. Bajan C. 1982. The effect of mineral fertilization on development and growth of chosen entomopathogenic and saprobiotic fungi. Polish Ecological Studies, 8(3-4), 473-487.

3. Bajan C., Kmitowa K. 1997. Thirty years studies on entomopathogenic fungi in the Institute of Ecology PAS. Polish Ecological Studies, 23(3-4), 133-154.

4. Bałazy S. 2004. Znaczenie obszarów chronionych dla zachowania zasobów grzybów entomopatogenicznych. Kosmos. Problemy Nauk Biologicznych, 53(1), 133-141.

5. Barabasz W., Filipek-Mazur B., Mazur K., Chmiel M., Grzyb J., Frączek K. 1999. Aktywność mikrobiologiczna gleby w 30-tym roku statycznego doświadczenia nawozowego w Czarnym Potoku koło Krynicy. Zeszyty Problemowe Postępu Nauk Rolniczych, 465, 647-655.

6. Bing L.A., Lewis L.C. 1993. Occurrence of the entomopathogen Beauveria bassiana (Balsamo) Vuillemin in different tillage regimes and in Zea mays and virulence towards Ostrinia nubilalis (Hubner). Agriculture, Ecosystems and Environment, 45,147-156.

7. Bischoff J.F., Rehner S.A., Humber R.A. 2006. Metarhizium frigidum sp. nov.: a cryptic species of M. anisopliae and member of the M. flavoviridae complex. Mycologia, 98, 737-745.

8. Bischoff J.F., Rehner S.A., Humber R.A. 2009. A. multilocus phylogeny of the Metarhizium anisopliae lineage. Mycologia, 101, 512-530.

9. Faria M.R., Wraight S.P. 2007. Mycoinsecticides and mycoacaricides: A comprehensive list with worldwide coverage and international classification of formulation types. Biological Control, 43, 237-256.

10. Goettel M.S., Ingelis G.D., Johnson D.L., Fargues J. 1995. Field application of Beauveria bassiana for control of grasshoppers. Proceedings of the congress Microbial control agents in sustainable agriculture, Saint Vincent, Italy (Aosta).

11. Gondek K., Ropek D. 2007. Wybrane właściwości gleby pod trwałym użytkiem zielonym oraz aktywność owadobójczych nicieni i grzybów. Acta Agrophysica, 10(2), 327-340.

12. Gorczyca A. 2006. Effect of selected fertilizers on Beauveria bassiana (Balls.) Vuill entomopathogenic fungus. Part I growth. Ecological Chemistry and Engineering, 13(1-2), 37-42.

13. Górska E.B., Maciejewska A., Jakubiak I., Russel S. 2006. Wpływ obornika, torfu, węgla brunatnego i preparatu Rekulter na występowanie promieniowców w glebie. Zeszyty Naukowe Uniwersytetu Przyrodniczego we Wrocławiu 546, Rolnictwo, 89, 79-86.

14. Hirose E., Naves P.M.O.J., Zequi J.A.C., Martins L.H., Peralta C.H., Moinor Jr.A. 2001. Effect of biofertilizers and neem oil on the entomopathogenic fungi Beauveria bassiana (Balls.) Vuill and Metarhizium anisopliae (Metsch.) Brazilian Archives of Biology and Technology, 44(4), 419-423.

15. Humber, A.R. 2012. Identification of entomopathogenic fungi. Chapter VI, in: Lacey, L.A. (Ed.) Manual of techniques in invertebrate pathology. Academic Press, 151-187.

16. Inglis, G.D, Enkerli, J., Goettel, M.S., 2012. Laboratory techniques used for entomopathogenic fungi: Hypocreales. Chapter VII, in: Lacey, L.A. (Ed.) Manual of techniques in invertebrate pathology. Academic Press, 189-253.

17. Jarmuł-Pietraszczyk J., Kamionek M., Wilkowski P. 2011. Effect of long fertilisation on seasonal variability of occurrence of entomopathogenic nematodes and fungi. Ecological Chemistry and Engineering, 18(3), 359-363.

18. Jarmuł-Pietraszczyk, J., Tkaczuk, C., Kamionek, M., Pezowicz, E. 2008. Effects of long- term mineral and organic fertilization on the occurrence of entomopathogenic fungi in soil. Ecological Chemistry and Engineering, 15(4), 349-353.

19. Jaworska M., Ropek J., Ropek D., Kopeć M. 2002. Effect of diversified organic fertilization with sludge from tannery sewage treatment plant on the occurrence and pathogenicity of entomopathogenic fungi and nematodes. Chemia i Inżynieria Ekologiczna, 9(4), 407-412.

20. Karg J., Bałazy S. 2009. Wpływ struktury krajobrazu na występowanie agrofagów i ich antagonistów w uprawach rolniczych. Progress in Plant Protection/Postępy w Ochronie Roślin, 49(3), 1015-1034.

21. Keller S., Kessler P., Schweizer C. 2003. Distribution of insect pathogenic soil fungi in Switzerland with special reference to Beauveria brongniartii and Metarhizium anisopliae. Biocontrol, 48, 307-319.

22. Klingen I., Eilenberg J., Meadow R. 2002. Effects of farming system field margins and bait insect on the occurrence of insect pathogenic fungi in soils. 
Agriculture, Ecosystems and Environment, 91, 191-198.

23. Klingen I., Haukeland S. 2006. The soil as a reservoir for natural enemies of pest insects and mites with emphasis on fungi and nematodes. In: Eilenberg J., Hokkanen H.M.T. (Eds.) An ecological and societal approach to biological control. Progress in biological control, vol. 2. Springer, Netherlands, 145-211.

24. Lingg A.J., Donaldson M.D. 1981. Biotic and abiotic factors affecting stability of Beauveria bassiana conidia in soil. Journal of Invertebrate Pathology, 38,191-200.

25. Meyling N.V., Eilenberg J. 2006. Occurrence and distribution of soil borne entomopathogenic fungi within a single organic agroecosystem. Agriculture, Ecosystems and Environment, 113, 336-341.

26. Musierowicz A. 1938. Z badań nad wartością nawozową miału węgla brunatnego. Przegląd Doświadczalnictwa Rolniczego, 1 (6).

27. Myśków W. 1981. Próby wykorzystania wskaźników aktywności mikrobiologicznej do oceny żyzności gleby. Postępy Mikrobiologii, 20, 173-192.

28. Quesada-Moraga E., Navas-Cortes J.A., Maranhao A.A., Ortiz-Urquiza A., S., Santiago-Alvarez C. 2007. Factors affecting the occurrence and distribution of entomopathogenic fungi in natural and cultivated soils. Mycological Research, 111, 947-966.

29. Rosin F., Shapiro D.I., Lewis L.C. 1996. Effects of fertilizers on the survival of Beauveria bassiana. Journal of Invertebrate Pathology, 68, 194-195.

30. Sas-Paszt L., Głuszek S., Grzyb Z. 2013. Możliwość wykorzystania węgla brunatnego do stosowania w rolnictwie ekologicznym. Eko Tech Produkt, 16, 1-5.

31. Shapiro-Ilan DI., Gardner W.A., Wells L., Cottrell T.E., Behle R.W., Wood B.W. 2013. Effects of entomopathogenic fungus species, and impact of fertilizers, on biological control of pecan weevil (Coleoptera: Curculionidae). Environmental Entomology, 42(2), 253-261.

32. Sosa-Gomez D.R., Delpin K.E., Moscardi F., Farias J.R.B. 2001. Natural occurrence of the entomopathogenic fungi Metarhizium, Beauveria and Paecilomyces in soybean under till and no-till cultivation systems. Neotropical Entomology, 30(3), 407-410.

33. Sosnowska D. 2013. Postępy w badaniach i wykorzystanie grzybów pasożytniczych w integrowanej ochronie roślin. Progress in Plant Protection/Postępy w Ochronie Roślin, 53 (4), 747-750.
34. Strasser H., Forrer A., Schinner F. 1996. Development of media fort the selective isolation and maintenance of virulence of Baeuveria brongniartii. (In:) T.A. Jackson, T.R. Glare (eds).Microbiol control of soil dwelling pests. AgResearch, Lincoln, New Zeland, 125-130.

35. Symanowicz B., Kalembasa S., Jaremko D., Niedbała M. 2013. Polskie odpadowe węgle brunatne - potencjalne źródło składników pokarmowych. Annales UMCS sec. E Agricultura, 68(4), 21-27.

36. Tkaczuk C. 2008. Występowanie i potencjał infekcyjny grzybów owadobójczych w glebach agrocenoza i środowisk seminaturalnych w krajobrazie rolniczym. Rozprawa Naukowa nr 94, Wydawnictwo Akademii Podlaskiej, 160 ss.

37. Tkaczuk C., Król A., Majchrowska-Safaryan A., Niecewicz Ł. 2014. The occurrence of entomopathogenic fungi in soils from fields cultivated in a conventional and organic system. Journal of Ecological Enginering, 15(3), 137-144.

38. Tkaczuk C., Majchrowska-Safaryan A., Głuszczak B. 2016b. Wpływ wybranych środków ochrony roślin dopuszczonych do stosowania w uprawach ekologicznych na wzrost grzybów owadobójczych. Progress in Plant Protection, 56(3), 265-271.

39. Tkaczuk C., Majchrowska-Safaryan A., Harasimiuk M. 2016a. Występowanie oraz potencjał infekcyjny grzybów entomopatogenicznych w glebach z pól uprawnych, łąk i siedlisk leśnych. Progress in Plant Protection, 56(1), 5-11.

40. Tkaczuk C., Majchrowska-Safaryan A., Miętkiewski R. 2013. Wpływ wybranych fungicydów oraz wyciągów glebowych na wzrost owadobójczego grzyba Metarhizium anisopliae. Progress in Plant Protection/Postępy w Ochronie Roślin, 53(4), 751-756.

41. Townsend R.J., O’Callagham M., Johanson V.W., Jackson T.A. 2003. Compatibility of microbial agents Serratia entomophila and Beauveria bassiana with selected fertilizers. New Zealand Plant Protection, 56, 118-122.

42. Ustawa o odpadach $\mathrm{z}$ dnia 14 grudnia $2012 \mathrm{r}$. (Dz.U. z 2013 r. poz. 21).

43. Ustawa z dnia 10 lipca 2007 r. o nawozach i nawożeniu (Dz. U. Nr 147 poz. 1033).

44. Vänninen I. 1996. Distribution and occurrence of four entomopatogenic fungi in Finland: Effect of geographical location, habitat type and soil type. Mycological Research, 100, 93-101.

45. Zimmermann G. 1986. Galleria bait method for detection of entomopathogenic fungi in soil. Journal of Applied Entomology, 2, 213-215. 